\title{
Alterations in milk metabolome and coagulation ability during the lactation of dairy cows
}

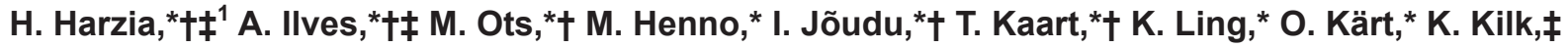 \\ and U. Soometsł \\ *Institute of Veterinary Medicine and Animal Science, Estonian University of Life Sciences, Kreutzwaldi 1, Tartu 51014, Estonia \\ †Bio-Competence Centre of Healthy Dairy Products, Kreutzwaldi 1, 51014 Tartu, Estonia \\ fDepartment of Biochemistry, Medical Faculty, University of Tartu, the Centre of Excellence for Translational Medicine, 50411 Tartu, Estonia
}

\section{ABSTRACT}

Milk composition has been known to change during lactation. To help understand the changes in metabolic profile throughout the whole lactation, liquid chromatography mass-spectrometry was used to analyze 306 milk samples from 82 primi- and multiparous dairy cows. Changes in metabolic profile common to all cows throughout lactation were ascertained based on principal component and general linear model analysis. Sets of specific markers; for instance, 225, 397, and 641-642 $\mathrm{m} / z$ (positive mode), and 186, 241, and 601-604 (negative mode), with at least a 1.5-fold higher intensity during the first $60 \mathrm{~d}$ compared with the last $60 \mathrm{~d}$ of lactation were observed. The metabolome was affected by parity and milking time. Markers, identified as peptides differentiating parity, were observed. A significant increase for citrate was observed in evening milk. Milk coagulation traits were strongly animal specific. The curd firmness values were influenced by milking time. Sets of markers were associated with curd firmness in positive $(197 \mathrm{~m} / \mathrm{z})$ and negative $(612,737,835,836$, 902, 1000, 1038, and $1079 \mathrm{~m} / z$ ) ion mode.

Key words: lactation curve, milk metabolite, coagulation

\section{INTRODUCTION}

Metabolomics has been introduced recently to animal and dairy science. Being routinely collected, milk is a suitable substance for monitoring analyses. A better understanding of the milk metabolome would advance its use in evaluating the state of the animals and milk technological properties. Milk composition and pro-

Received March 14, 2013.

Accepted June 19, 2013.

${ }^{1}$ Corresponding author: hedi.harzia@emu.ee duction are affected by inherent and external factors, directly or indirectly. Differences in milk composition may be caused by nutritional (Malossini et al., 1996) or nonnutritional factors such as stage of lactation (Jõudu et al., 2008; Stoop et al., 2009). Using nuclear magnetic resonance (Klein et al., 2010, 2012) and GC-MS (Klein et al., 2010) for targeted analyses, a change in the metabolic composition of milk throughout the lactation has been observed. In a recent study by Ilves et al. (2012), using a mass spectrometric approach (liquid chromatography-tandem MS; LC-MS/MS), changes in the milk metabolome in early lactation were observed, specifically decreases in phosphorylated saccharides, citrate, and lactose concentrations. Melzer et al. (2013) also showed changes in the metabolome up to d 120 of lactation; metabolites that correlated with milk traits were detected. However, one limitation of the study was the lack of multiple samples from the same cow over the lactation (Melzer et al., 2013). Hence, the aim of this study was to provide greater understanding of the changes in the metabolic profile throughout the whole lactation, involving several samples per cow and using untargeted global metabolomics with LC-MS/MS.

Coagulation, an important trait of milk technological quality, is influenced by lactation stage and other factors (Grandison et al., 1984; Auldist et al., 2002; Cassandro et al., 2008). Previously, Harzia et al. (2012) identified the difference in the metabolome of noncoagulating and coagulating milk, and differences in metabolic profiles of milk with different coagulation abilities have been reported by Sundekilde et al. (2011). The metabolites related to coagulation properties include citrate, choline, carnitine, lactose, and other oligosaccharides such as N-acetyllactosamine (NAcLac; Sundekilde et al., 2011; Harzia et al., 2012). Nevertheless, the change in milk metabolome throughout lactation and relationships with coagulation ability need to be investigated further; therefore, a second objective of this study was to identify correlations between metabolome and coagulation ability. 


\section{MATERIALS AND METHODS}

\section{Animal Management and Feeding}

Animal use and care were in accordance with the Estonian Animal Protection Act. Cows in a loose housing system on the Estonian University of Life Sciences' experimental farm (Eerika Farm LLC, Märja, Estonia) were milked twice a day and fed TMR ad libitum year round. Three rations were used: ration 1 consisted of (DM) $40 \%$ silage, $58 \%$ concentrates, and $2 \%$ minerals, $11.3 \mathrm{MJ}$ of ME, $160 \mathrm{~g} / \mathrm{kg} \mathrm{CP}$, and $103 \mathrm{~g} /$ $\mathrm{kg}$ MP; ration 2 consisted (DM) $48 \%$ silage, $50 \%$ concentrates, and $2 \%$ minerals, $10.7 \mathrm{MJ}$ of $\mathrm{ME}, 159 \mathrm{~g} / \mathrm{kg}$ $\mathrm{CP}$, and $97 \mathrm{~g} / \mathrm{kg} \mathrm{MP}$; and ration 3 consisted of (DM) $73 \%$ silage, $25 \%$ concentrates, and $2 \%$ minerals, 9.7 MJ of ME, $143 \mathrm{~g} / \mathrm{kg} \mathrm{CP}$, and $85 \mathrm{~g} / \mathrm{kg}$ MP. The rations comprised grass (75\%) and clover (25\%) silage; barley, wheat, and maize meal; heat-treated rapeseed cake, limestone, sodium chloride, and a vitamin-mineral mix for lactating cows. After calving, the cows were fed with ration 2 up to 14 DIM, after which ration 1 was offered up to $6.5 \mathrm{mo}$ of lactation or if milk production was still $>30 \mathrm{~kg} / \mathrm{d}$. Thereafter, the cows were again fed ration 2 and, at 1 mo before drying off, ration 3 was applied.

\section{Sample Collection and Analysis}

Milk samples $(40 \mathrm{~mL} ; \mathrm{n}=306,3.73$ replicates per cow, $6, \ldots, 307$ DIM) from 82 primi- and multiparous ( $\mathrm{n}=156$ and 150, respectively) Estonian Holstein (n $=70)$, Estonian Red $(\mathrm{n}=7)$, and Estonian Native (n $=5$ ) dairy cows were collected from February 2011 to February 2012 once a month with in-line milk meters within the framework of regular animal recording.

Milk samples were analyzed for fat, protein, and SCC content at the laboratory of Estonian Animal Recording Centre. Curd firmness $\left(\mathbf{E}_{30}, \mathrm{~mm}\right)$ and coagulation time (RCT, min) were analyzed with an Optigraph as described by Kübarsepp et al. (2005), and milk pH was recorded ( $\mathrm{pH}$ meter, SevenMulti; Mettler Toledo $\mathrm{GmbH}$, Greifensee, Switzerland). Milk samples were prepared and MS analyses were performed on an LCMS/MS (3200 Q TRAP; AB Sciex Instruments, Framingham, MA) as described by Harzia et al. (2012).

\section{Statistical Analysis}

Mass spectral data were preprocessed by binning data to atomic mass unit resolution. The principal component analyses (PCA) were performed for $m / z$ in positive and negative ion mode to discover the potential patterns in MS data for differently ionized metabolites. To study the alterations of milk metabolome during the lactation, the identified principal components (PC) were modeled following the general linear mixed (GLM) model:

$$
\begin{aligned}
y_{i j k l m} & =\mu+B_{i}+P_{j}+D_{k}+M_{l}+b_{1} \times L D I M_{i j k l m} \\
& +b_{2} \times L D I M_{i j k l m}^{2}+b_{3} \times L D I M_{i j k l m}^{3}+C_{m}+e_{i j k l m},
\end{aligned}
$$

where $y_{i j k l m}$ is the dependent variable, $\mu$ is the model intercept, $B_{i}$ is the breed effect $(i=1,2,3), P_{j}$ is the parity effect $(j=1,2$; primi- and multiparous), $D_{k}$ is the diet effect $(k=1,2,3), M_{l}$ is the milking time effect ( $l=1,2$; morning and evening), $b_{1} \times L D I M_{i j k l m}+b_{2} \times L D I M_{i j k l m}^{2}+b_{3} \times L D I M_{i j k l m}^{3}$ is the third-order Lagrange polynomial of DIM, $C_{m}$ is the random cow effect $(m=1, \ldots, 82)$, and $e_{i j k l m}$ is the model error. The same model was applied to study alterations in milk coagulation and production and composition traits during the lactation. To examine the relationships between different milk traits and milk metabolome during 3 different lactation stages - the beginning (the first $60 \mathrm{~d}$ ), middle (mo 3 to 8 ), and the end of lactation (the last $60 \mathrm{~d}$ ) - Spearman rank correlation analysis was performed considering also the binary dummy variables of parity and milking time.

Statistical significance between $\mathrm{m} / \mathrm{z}$ intensities in the spectra of early and late lactation milk, morning and evening milkings, and the first and second to third parities was determined by Student's $t$-tests. Results were displayed on a volcano plot as the distribution of signal intensities relative to the mean at respective $\mathrm{m} / \mathrm{z}$ values, which were ranked based on calculated statistical differences. Statistical analyses were performed with SAS software (version 9.1; SAS Institute Inc., Cary, NC) and with R 2.8.1 /BioConductor algorithms (R Development Core Team, 2009).

\section{RESULTS AND DISCUSSION}

\section{Lactational Curves of Milk Characteristics}

As the biological needs of the calf changes with age, milk composition alters as lactation progresses (Walstra, 1999). The GLM analyses of production, composition, and quality traits during lactation are presented in Figure 1; no abnormal dynamics were observed. Changes in milk yield and fat and protein contents were similar to those of Mucha and Strandberg (2011) and Stoop et al. (2009). Fat content changed contrarily to milk yield, declining during the first $100 \mathrm{~d}$ (from 4.49 to $3.85 \%$ ) and 



Figure 1. Change in milk production and composition traits (with $95 \%$ CI) during lactation estimated with third-order polynomial according to the linear mixed model considering additionally fixed effects of breed, parity (primi- and multiparous), diet, and milking time (morning and evening) and random effect of cow; $\mathrm{SCS}=\left[\log _{2}(\mathrm{SCC} / 100,000)+3\right] . \mathrm{E}_{30}=$ curd firmness; $\mathrm{RCT}=$ rennet coagulation time.

then increasing to d $259(4.29 \%)$. Milk yield reached its peak at the end of mo $2(30.5 \mathrm{~kg} / \mathrm{d})$ and then declined to $\mathrm{d} 251(24.16 \mathrm{~kg} / \mathrm{d})$. Protein percentage declined over the first $57 \mathrm{~d}$ (from 3.32 to $3.20 \%$ ) and then increased to peak level on d 263 (3.74\%). Somatic cell score, calculated as SCS $=\left[\log _{2}(\mathrm{SCC} / 100,000)+3\right]$, had its lowest value at 76 DIM $($ SCS $=8.61)$ and highest value on 236 DIM (SCS $=9.08)$. 

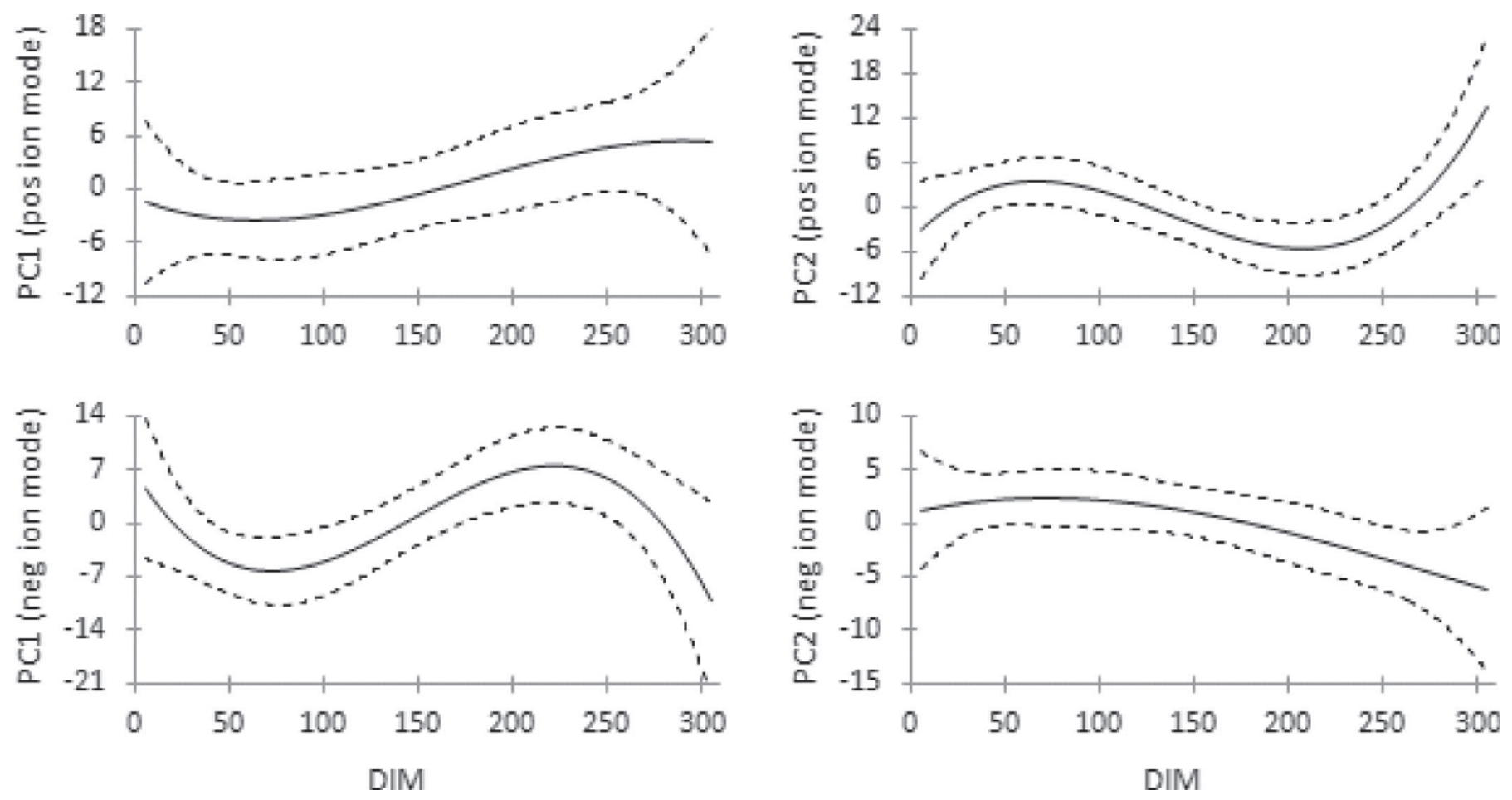

Figure 2. Results of principal component (PC) analyses of mass/charge ratio $(\mathrm{m} / z)$ in positive (pos) and negative (neg) ion mode. Change in the first 2 principal component values (with 95\% CI) during lactation estimated with third-order polynomial according to the linear mixed model considering additionally fixed effects of breed, parity (primi- and multiparous), diet and milking time (morning and evening) and random effect of cow are presented.

\section{Influence of Lactation on Metabolome}

To improve our understanding of the change in metabolic profile throughout the whole lactation, PCA and GLM analyses were conducted. The results revealed 2 main patterns among MS signals from milk metabolites characterized by a linear or higher degree relationship to DIM (Figure 2, Table 1). One of the patterns reflected the difference between the first and second halves of lactation, whereas the other pattern (PC2 in positive and $\mathrm{PC} 1$ in negative ion mode) changed rapidly during the first 2 lactation months, achieved its initial value within the next 5 to $6 \mathrm{mo}$, and changed again, as at the beginning of the lactation, within mo 8 to 10 of lactation. Based on the loading plots, the first $2 \mathrm{PC}$ accounted for more than $50 \%$ of the total variance of the measured signals either in positive or negative ion mode (Figure 3). The subsequent PC accounted for $<8 \%$ of total variance each. As the first 2 PC were slightly related to almost every metabolic marker but at the same time no single metabolite existed with stronger contributions (Figure 3), the patterns described in Figure 2 are common to the whole milk metabolome and reflect general physiological changes during lactation. According to the modeling results of the PC (Table 1), no animal-specific component existed in the 2 first PC. This confirms that the discovered metabolic profiles are common to all cows; a common evolution for the direction of the metabolic profile from the first to the second month of lactation was observed previously (Ilves et al., 2012).

All modeled PC had different values at the beginning and at the end of the lactation. To obtain more information on these differences, the metabolic profile from the first $60 \mathrm{~d}$ was compared with that of the last $60 \mathrm{~d}$ of lactation. The results were visualized on volcano plots (Figure $4 \mathrm{~A}$ and $4 \mathrm{~B}$ ) as the change in mean signal intensity versus the statistical significance of the change. The most significant $\left(P<10^{-16} ;\right.$ a $>1.5$-fold change in signal intensity) decrease during lactation was observed for a set of markers 225, 299, 397, 641, and $642 \mathrm{~m} / \mathrm{z}$ (measured in positive mode), and 186, 241, 258-260, 289-290, 322, 357, 423-425, 466, 468, 486, 601-604, 622, 664, 699, 737, and 943-944 $\mathrm{m} / \mathrm{z}$ (measured in negative mode). All these signals had a higher intensity in early lactation compared with late lactation. On the other hand, a significant increase of intensity during lactation showed only $m / z 220$ and 256 (Figure 4B). The findings of the current study expand previous results (Ilves et al., 2012) that indicated a decrease of several milk 
Table 1. Modeling results of principal components of signals measured in positive and negative ion mode and milk coagulation, production, and composition traits

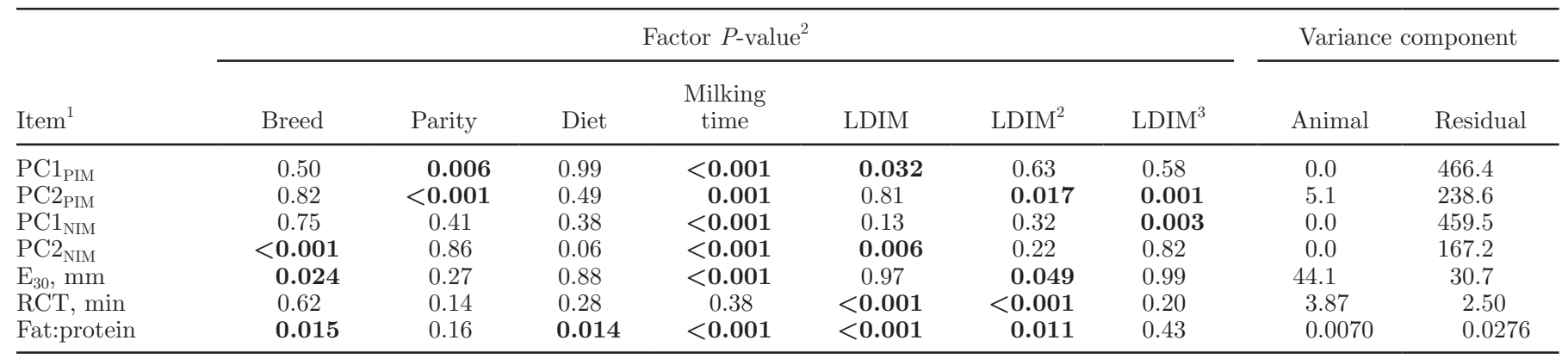

${ }^{1} \mathrm{PC}=$ principal component, $\mathrm{PIM}=$ positive ion mode, $\mathrm{NIM}=$ negative ion mode; $\mathrm{E} 30=$ curd firmness; $\mathrm{RCT}=$ milk (rennet) coagulation time. ${ }^{2}$ LDIM, LDIM ${ }^{2}, \mathrm{LDIM}^{3}=$ linear, quadratic, and cubic effects, respectively, of DIM modeled as Lagrange polynomial. Statistically significant effects $(P<0.05)$ are shown in bold type.

metabolites in negative mode by the start of mo 3 of lactation. Additionally, the decrease of signals 421-422, $426,482,606-608,648$, and 666 prevailing during the first 3 mo of lactation (Ilves et al., 2012) remained significant $(P<0.001$, Figure 4B) throughout the lactation. Ilves et al. (2012) identified the signal with $\mathrm{m} / \mathrm{z}$ 421 (negative mode) as lactose phosphate and noted that $m / z$ 601-603 matched with $m / z 421$ spectra and could be a noncovalent complex with additional hexose or a covalent hexose + water complex.

Signal $\mathrm{m} / z 218$ measured in negative mode (Figure 4B) was previously associated with feeding of crude glycerol and identified as pantothenic acid (Harzia et al., 2013). According to previous studies (Lardinois et al., 1944; Hollis et al., 1954; Hayes et al., 1967), the synthesis of pantothenic acid depends on the diet and increases as the supplementation of rapidly degradable carbohydrates is increased. In the present study, the higher intensity of pantothenic acid at the beginning of lactation could be related to the high level of concentrates (up to $62 \%$ of DM) in TMR during the highyielding period.

The findings of the current study are consistent with those of Melzer et al. (2013), who found that day of lactation had a significant influence on $45.8 \%$ of the 190 metabolites studied; metabolite profiles from the beginning of lactation (21-50 DIM) clustered together, as did the later ones. However, only milk samples from
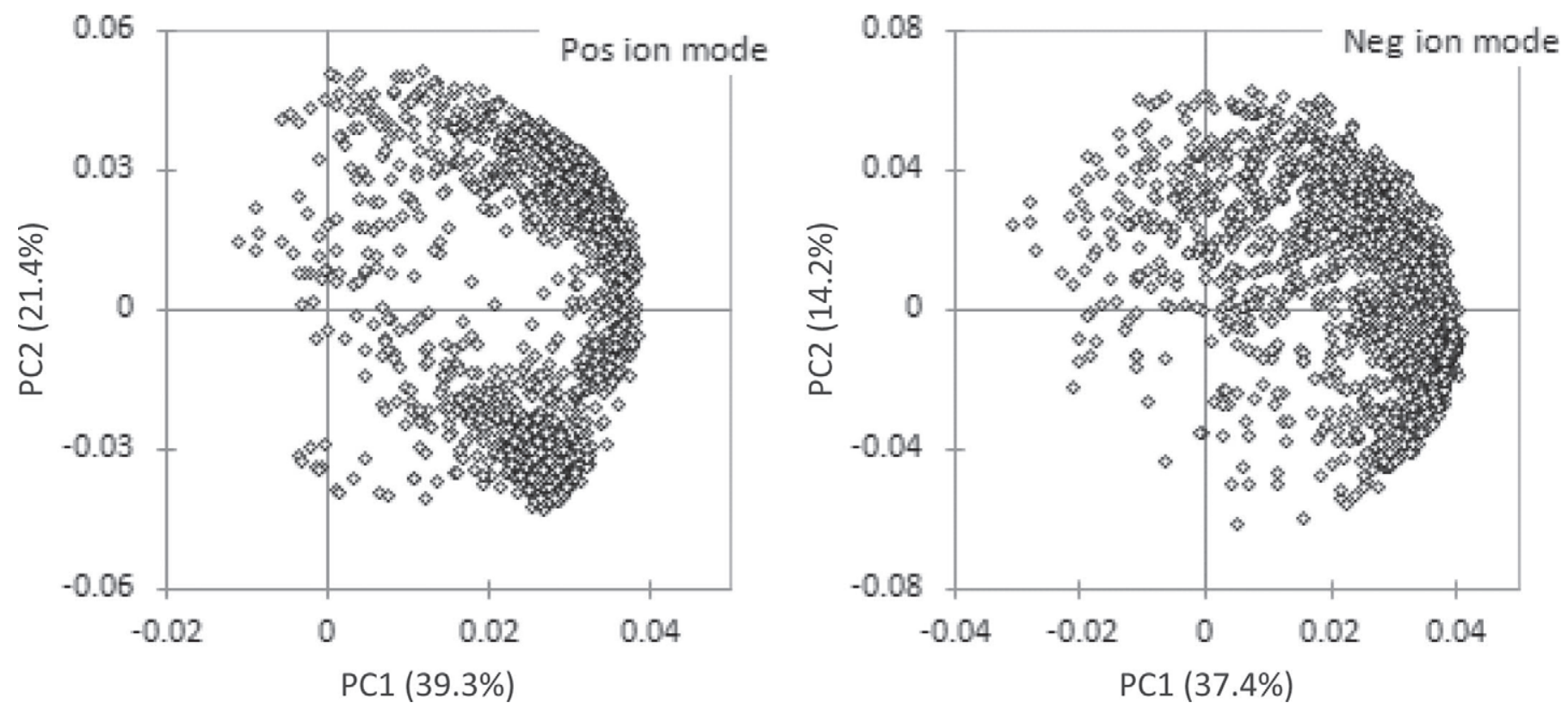

Figure 3. Loading plots of principal component (PC) analyses and their account of total variances of MS signals measured in positive (pos) and negative (neg) ion mode. 

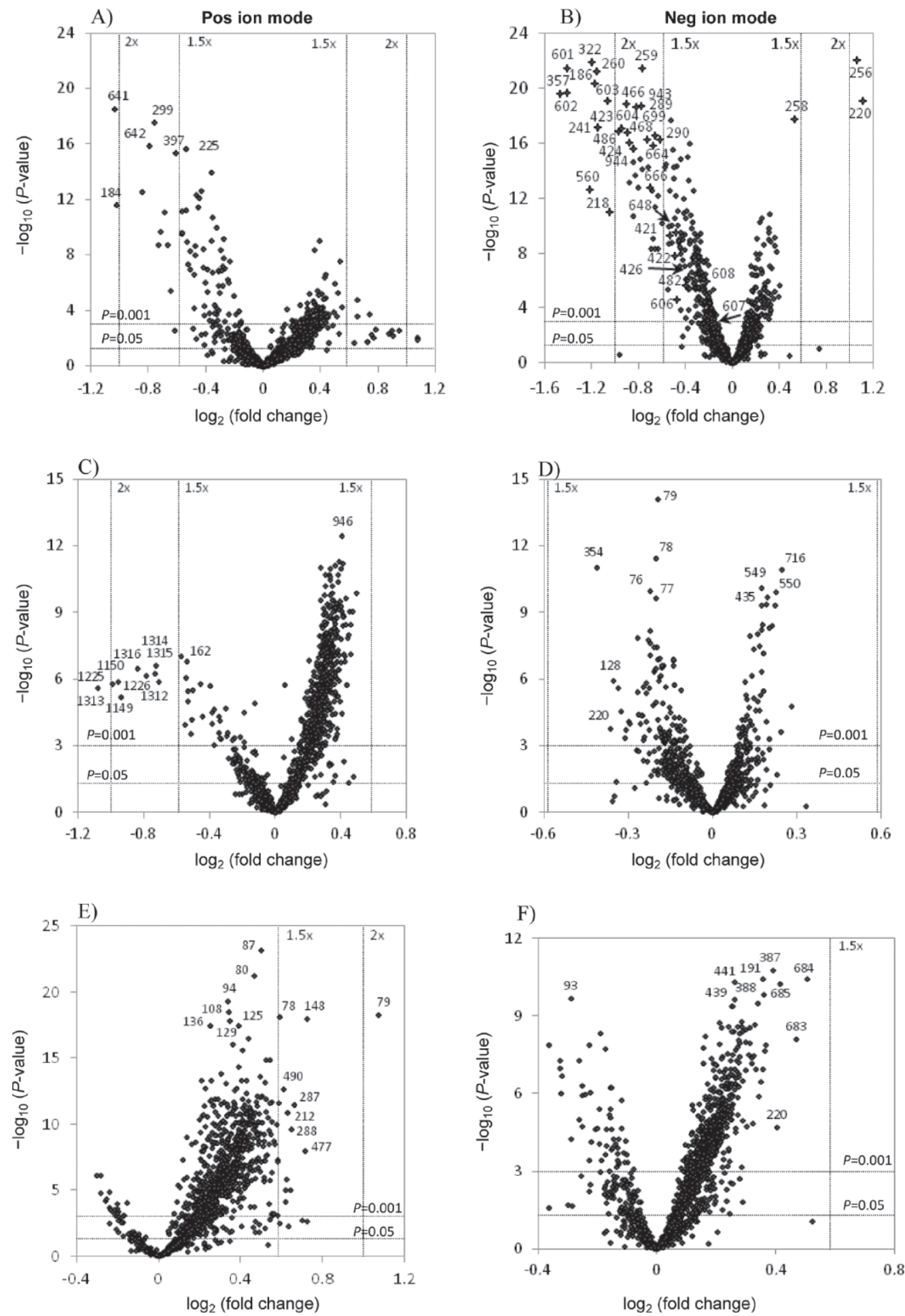

Figure 4. Volcano plots displaying the fold change in mass-to-charge ratio intensity (x-axis) versus the significance of the change (y-axis) for the (A, B) first and last $60 \mathrm{~d}$ of lactation in positive (pos; A) and negative ion mode (neg; B). Signals with the highest intensity and most significant change (decrease during lactation) in the first $60 \mathrm{~d}$ of lactation are in the upper left corner, signals with the highest and most significant intensity (increase during lactation) in the last $60 \mathrm{~d}$ of lactation are in the upper right corner; (C, D) as (A, B), but displaying difference of significance for primiparous and multiparous cows in positive (C) and negative (D) ion mode. Signals with the highest and most significant intensity in primiparous cows are in the upper left corner, signals with the highest and most significant intensity in multiparous cows are in the upper right corner; (E, F) as (A, B), but displaying difference of significance between morning and evening milk samples in positive (E) and negative $(\mathrm{F})$ ion mode. The most significant signals with the highest intensity in the morning milk samples are in the upper left corner, the evening milk samples are in the upper right corner. 
primiparous cows ( 1 sample per cow) during the period of 21 to 120 DIM were analyzed in Melzer et al. (2013).

The results of this study indicate that the milk metabolome differs between lactation periods. The physiological drive for changes could be the change in the needs of the suckling offspring, different milk yield during lactation, different metabolic state (i.e., utilization of fat and protein reserves for milk production at the beginning of lactation, the negative energy balance period), and, starting from conception, the metabolic needs of the fetus. In their review, Grummer and Rastani (2003) noted that, in $90 \%$ of cases, cows reach a positive energy balance by $63 \mathrm{~d}$ postpartum, the approximate time of the first turning point of the lactation curves of PC1 (negative mode) and PC2 (positive mode) in the present study. Hence, the results of our research implicitly support the idea that the milk metabolome is affected by the energy balance of the dairy cow. However, a limitation of our study is that the energy balance data for the cows are not available. Although milk fat to protein ratio (Figure 1), an indirect indicator used for energy balance estimation, was higher at the beginning of the lactation, it did not exceed the threshold level at 1.5 (Heuer et al., 2000) and was influenced by the ration of the cows (Table 1). Effect of pregnancy on milk yield and composition has been observed from the first day of gestation; the change, dependent on lactation stage (the influence being less noteworthy at the end of lactation; Olori et al., 1997), becomes significant from mo 5 of gestation onward (Olori et al., 1997; Roche, 2003). In the present study, the mean of the period open was $140 \mathrm{~d}$ and the change in the lactation curves of milk yield, fat and protein percentages, and PC1 (negative mode) and PC2 (positive mode) occurred around mo 3 of gestation.

\section{Influence of Parity on Metabolome}

As parity influenced both $\mathrm{PC}$ in positive ion mode (Table 1), the metabolic profiles of primi- and multiparous cows over the whole lactation were compared. The analyses in positive mode showed that signals with the highest and most significantly different intensities in primiparous cows compared with multiparous cows (Figure $4 \mathrm{C}$ ) have $m / z>1,000$ Da. Markers with $m / z$ of around 1,000 could indicate the presence of polymers, including peptides and lipids. This finding might therefore indicate the greater presence of peptides in the primiparous milk metabolome, which could be explained by the difference in milk protein content. In Estonian cows, depending on parity, protein content decreases with parity number (Jõudluskontrolli Keskus, 2012). The presence of the same set of signals did not depend on milking time or on beginning or end of lacta- tion (Figure 4A, B, E, and F). In addition, signals with the highest and most significantly different intensities in multiparous cows compared with primiparous cows (Figure 4C and D) were detected (in positive mode 946 $\mathrm{m} / z$, and in negative mode $435,549,550$, and $716 \mathrm{~m} / z$ ). The difference between a cow's metabolome in different parities could be related to differences in energy consumption and utilization in first-lactation dairy heifers compared with older cows. First-lactation dairy cows are still growing and they do not give as much milk as multiparous cows.

\section{Influence of Milking Time on Metabolome}

As expected (Gilbert et al., 1973; Palmer et al., 1994), milking time had an effect on almost all variables studied (Table 1 ). The PC values were significantly influenced by milking time; the estimated values of the first PC in both positive and negative ion modes were higher at evening milking and those of the second PC were higher at morning milking, according to the GLM. All these effects remained the same after omitting the nonsignificant factors. The metabolic profiles of morning and evening milk samples were compared and a significant difference was observed in positive ion mode (Figure 4E), with signal $79 \mathrm{~m} / z$ having the highest and significantly different intensity in evening milk. In negative ion mode, $m / z 93$ had the highest intensity in morning milking. A significant increase for signal 191 $m / z$, indicating citrate, measured in negative ion mode, was observed in evening milk (Figure 4F). According to Faulkner and Peaker (1982), citrate concentration is positively associated with the fat content of milk, which is in good accord with our results (data not shown).

\section{Metabolome Influence on Milk Coagulation}

The GLM results of coagulation parameters are presented in Figure 1 and Table 1. The estimated curve for $\mathrm{E}_{30}$ was persistent, without noticeable peaks, and maintained favorable values throughout the lactation. In agreement with the results of Ostersen et al. (1997), the estimated $\mathrm{E}_{30}$ was optimal $(>32 \mathrm{~mm})$ at the beginning and end of lactation and lowest during mid lactation (30.42 $\mathrm{mm}$ on d 157). Greater variation in $\mathrm{E}_{30}$ was observed by Vallas et al. (2010), but trajectories describing $\mathrm{RCT}$ were consistent in the 2 studies. Estimated RCT increased to the end of mid lactation, being lowest during the first $18 \mathrm{~d}(<6 \mathrm{~min})$ and highest during mid lactation (d 172-238, mean value between 9.90 and $9.99 \mathrm{~min})$. At the end of lactation, RCT decreased until it reached $9.55 \mathrm{~min}$. Increase in RCT has previously (Grandison et al., 1984; Ostersen et al., 1997; Kübarsepp et al., 2005) been associated with in- 

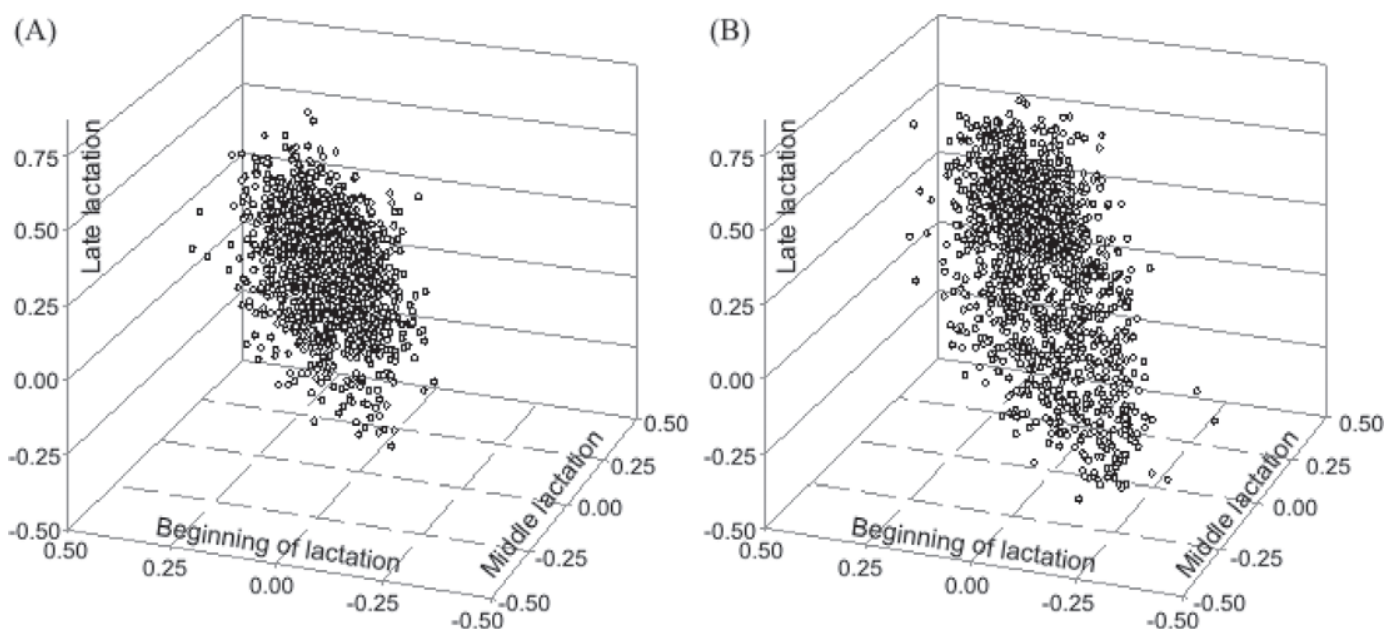

Figure 5. Spearman rank correlation coefficients between curd firmness $\left(\mathrm{E}_{30}\right)$ and signals measured in $(\mathrm{A})$ positive and (B) negative ion mode; each dot corresponds to 1 signal and represents its correlations with $\mathrm{E}_{30}$ at 3 different lactation stages.

creased pH. Lactational changes in curd firmness have previously been associated with variation in milk composition, mainly with milk protein and their fraction contents (Guinee, 2003; Jõudu et al., 2007, 2008). In addition to general lactational dynamics, the modeling results of milk coagulation traits (Table 1 ) revealed that the values of these traits are strongly animal specific: the proportion of variance related to individuals varied from 0.3 to 0.6 . In addition, $\mathrm{E}_{30}$ values were influenced by milking time: firmer curd and shorter RCT were observed at evening milking.

To verify the second objective, we studied the correlations between milk coagulation properties and milk metabolome at different lactation stages. Although no strong relationships were found, the direction and strength of the relationships were more or less the same at the beginning, middle, and end of the lactation (Figure 5). Two biomarkers were found in positive ion mode $(\mathrm{m} / z 197$ and 342$)$ and 8 in negative ion mode $(m / z=612,737,835,836,902,1000,1038$, and 1079), which had at least intermediate positive relationships (correlation coefficient $\mathrm{r}>0.3$ ) with $\mathrm{E}_{30}$ at every lactation stage. Both positive signals and 4 negative (902, 1000,1038 , and 1079) signals were positively correlated (correlation coefficient $r>0.3$ ) with protein throughout the lactation. We found no signals that had at least intermediate relationships with RCT at lactation stage.

\section{CONCLUSIONS}

The results revealed 2 main patterns among MS signals from milk metabolites characterized by a linear or a higher degree relationship to DIM. Sets of specific markers for lactation periods, parity, and milking time were ascertained. In addition, correlations between certain metabolites and coagulation ability persisted throughout lactation; no markers were linked to RCT.

\section{ACKNOWLEDGMENTS}

This work was supported by the targeted finance project SF0170165s08, Estonian Science Foundation grant 7856, and by the Bio-Competence Centre of Healthy Dairy Products co-financed by the European Community's Regional Development Fund within the framework of the Competence Centre Program of the Enterprise Estonia, project no. EU30002.

\section{REFERENCES}

Auldist, M., C. Mullins, B. O'Brien, B. T. O'Kennedy, and T. Guinee. 2002. Effect of cow breed on milk coagulation properties. Milchwissenschaft $57: 140-143$.

Cassandro, M., A. Comin, M. Ojala, R. Dal Zotto, M. De Marchi, L. Gallo, P. Carnier, and G. Bittante. 2008. Genetic parameters of milk coagulation properties and their relationships with milk yield and quality traits in Italian Holstein cows. J. Dairy Sci. 91:371-376.

Faulkner, A., and M. Peaker. 1982. Reviews of the progress of dairy science: Secretion of citrate into milk. J. Dairy Res. 49:159-169.

Gilbert, G. R., G. L. Hargrove, and M. Kroger. 1973. Diurnal variations in milk yield, fat yield, milk fat percentage, and milk protein percentage of Holstein-Friesian cows. J. Dairy Sci. 56:409-410.

Grandison, A. S., G. D. Ford, A. J. Owen, and D. Millard. 1984. Chemical composition and coagulating properties of renneted Friesian milk during the transition from winter rations to spring grazing. J. Dairy Res. 51:69-78.

Grummer, R. R., and R. R. Rastani. 2003. Review: When should lactating dairy cows reach positive energy balance? Prof. Anim. Sci. 19:197-203.

Guinee, T. P. 2003. Role of protein in cheese and cheese products. Pages 1083-1174 in Advanced Dairy Chemistry 1: Proteins, Vol. 1. Part B. P. F. Fox and P. L. H. McSweeney, ed. Kluver Academic/ Plenum Publisher, New York, NY.

Harzia, H., K. Kilk, T. Ariko, M. Kass, U. Soomets, I. Jõudu, T. Kaart, D. Arney, O. Kärt, and M. Ots. 2013. Crude glycerol as 
glycogenic precursor in feed: Effects on milk coagulation properties and metabolic profiles of dairy cows. J. Dairy Res. 80:190-196.

Harzia, H., K. Kilk, I. Jõudu, M. Henno, O. Kärt, and U. Soomets. 2012. Comparison of the metabolic profiles of noncoagulating and coagulating bovine milk. J. Dairy Sci. 95:533-540.

Hayes, B. W., G. E. Mitchell Jr., and C. O. Little. 1967. Factors affecting concentrations of B-vitamins in ruminal fluid in vitro. Int. Z. Vitaminforsch. 37:348-353.

Heuer, C., W. M. Van Straalen, Y. H. Schukken, A. Dirkzwager, and J. P. T. M. Noordhuizen. 2000. Prediction of energy balance in a high-yielding dairy herd in early lactation: Model development and precision. Livest. Prod. Sci. 65:91-105.

Hollis, L., C. F. Chappel, R. MacVicar, and C. K. Whitehair. 1954. Effect of ration on vitamin synthesis in rumen of sheep. J. Anim. Sci. 13:732-738.

Ilves, A., H. Harzia, K. Ling, M. Ots, U. Soomets, and K. Kilk. 2012 Alterations in milk and blood metabolomes during the first months of lactation in dairy cows. J. Dairy Sci. 95:5788-5797.

Jõudluskontrolli Keskus. 2012. Jõudluskontrolli aastaaruanded 2011 [Animal Control Annual Reports for 2011]. Elmatar, Tartu, Estonia.

Jõudu, I., M. Henno, T. Kaart, T. Püssa, and O. Kärt. 2008. The effect of milk protein contents on the rennet coagulation properties of milk from individual dairy cows. Int. Dairy J. 18:964-967.

Jõudu, I., M. Henno, S. Värv, T. Kaart, O. Kärt, and K. Kalamees, 2007. Milk protein genotypes and milk coagulation properties of Estonian native cattle. Agric. Food Sci. 16:222-231.

Klein, M. S., M. F. Almstetter, G. Schlamberger, N. Nürnberger, K. Dettmer, P. J. Oefner, H. H. D. Meyer, S. Wiedemann, and W. Gronwald. 2010. Nuclear magnetic resonance and mass spectrometry-based milk metabolomics in dairy cows during early and late lactation. J. Dairy Sci. 93:1539-1550.

Klein, M. S., N. Buttchereit, S. P. Miemczyk, A. K. Immervoll, C Louis, S. Wiedemann, W. Junge, G. Thaller, P. J. Oefner, and W. Gronwald. 2012. NMR metabolomic analysis of dairy cows reveals milk glycerophosphocholine to phosphocholine ratio as prognostic biomarker for risk of ketosis. J. Proteome Res. 11:1373-1381.

Kübarsepp, I., M. Henno, O. Kärt, and T. Tupasela. 2005. A comparison of the methods for determination of the rennet coagulation properties of milk. Acta Agric. Scand. A Anim. Sci. 55:145-148.

Lardinois, C. C., R. C. Mills, C. A. Elvehjem, and E. B. Hart. 1944 Rumen synthesis of the vitamin B complex as influenced by ration composition. J. Dairy Sci. 27:579-583.
Malossini, F., S. Bovolenta, C. Piras, M. DallaRosa, and W. Ventura. 1996. Effect of diet and breed on milk composition and rennet coagulation properties. Ann. Zootech. 45:29-40.

Melzer, N., D. Wittenburg, S. Hartwig, S. Jakubowski, U. Kesting, L. Willmitzer, J. Lisec, N. Reinsch, and D. Repsilber. 2013. Investigating associations between milk metabolite profiles and milk traits of Holstein cows. J. Dairy Sci. 96:1521-1534.

Mucha, S., and E. Strandberg. 2011. Genetic analysis of milk urea nitrogen and relationships with yield and fertility across lactation. J. Dairy Sci. 94:5665-5672.

Olori, V. E., S. Brotherstone, W. G. Hill, and B. J. McGuirk. 1997. Effect of gestation stage on milk yield and composition in Holstein Friesian dairy cattle. Livest. Prod. Sci. 52:167-176.

Ostersen, S., J. Foldager, and J. E. Hermansen. 1997. Effects of stage of lactation, milk protein genotype and body condition at calving on protein composition and renneting properties of bovine milk. J. Dairy Res. 64:207-219.

Palmer, R. W., E. L. Jensen, and A. R. Hardie. 1994. Removal of within-cow differences between morning and evening milk yields. J. Dairy Sci. 77:2663-2670.

R Development Core Team. 2008. R: A Language and Environment for Statistical Computing. R Foundation for Statistical Computing, Vienna, Austria. Accessed Sep. 15, 2012. http://www.R-project. org.

Roche, J. R. 2003. Effect of pregnancy on milk production and bodyweight from identical twin study. J. Dairy Sci. 86:777-783.

SAS Institute. 2008. SAS/STAT 9.1 User's Guide. SAS Inst. Inc. Cary, NC.

Stoop, W. M., H. Bovenhuis, J. M. L. Heck, and J. A. M. van Arendonk. 2009. Effect of lactation stage and energy status on milk fat composition of Holstein-Friesian cows. J. Dairy Sci. 92:1469-1478.

Sundekilde, U. K., P. D. Frederiksen, M. R. Clausen, L. B. Larsen, and H. C. Bertram. 2011. Relationship between the metabolite profile and technological properties of bovine milk from two dairy breeds elucidated by NMR-based metabolomics. J. Agric. Food Chem. 59:7360-7367.

Vallas, M., H. Bovenhuis, T. Kaart, K. Parna, H. Kiiman, and E. Parna. 2010. Genetic parameters for milk coagulation properties in Estonian Holstein cows. J. Dairy Sci. 93:3789-3796.

Walstra, P. 1999. Dairy Technology: Principles of Milk Properties and Processes. Food Science and Technology No. 90. Marcel Dekker, New York, NY 